\title{
Framework and Key Success Factors of Governance and Sustainability of Very Small Municipal Solid Waste Power Plants
}

\author{
Suwannee Missita*, Wisakha Phoochinda, Chamlong Poboon \\ Graduate School of Environmental Development Administration, National Institute of Development Administration, Bangkok \\ 10240, Thailand
}

Corresponding Author Email: suwannee.miss@ stu.nida.ac.th

https://doi.org/10.18280/ijsdp.160704

Received: 5 September 2021

Accepted: 16 November 2021

\section{Keywords:}

framework, governance, key success factor, municipal solid waste power plant, sustainability, very small power plant

\begin{abstract}
Inordinate municipal solid waste issues and ever increasing demand for electricity, the Thai government formulated the Power Development Plan focusing on supporting the use of renewable energy to generate electricity and using measures to promote the purchase of electricity from very small power producers. This support indubitably leads to the question as to whether Very Small Municipal Solid Waste Power Plants (VSMSWPPs) are sustainable or not. Thus, this study aims to develop a framework and key success factors for evaluating governance and sustainability of VSMSWPPs in Thailand. It consists of documentary research and interviews with professionals, policy makers, practitioners and power plant owners conducted to develop the framework and determine the key success factors. Subsequently, the framework and factors were assessed by 12 experts. The good governance and sustainability concepts were selected as a framework and used to construct key success factors to evaluate the performance of VSMSWPPs. The framework contains four dimensions and each dimension had key success factors as follows: (1) Governance dimension with 7 key success factors; (2) Economic dimension with 8 key success factors; (3) Social dimension with 5 key success factors; and (4) Environmental dimension with 7 key success factors: at total of 27 key success factors.
\end{abstract}

\section{INTRODUCTION}

Escalating municipal solid waste problems and rising electricity power consumption are increasingly areas of prime concern of the Thai government. To address these issues concurrently, the government is promoting waste separation mechanisms to recover and dispose of solid waste by transforming it into energy [1]. In the Thailand Power Development Plan 2015-2036 (PDP 2015), the net electricity power demand forecast for Thailand will be $326,119 \mathrm{GWh}$ or 27,789 ktoe in 2036 [2]. This will be used as a framework to formulate the target of the Alternative Energy Development Plan 2015 (AEDP 2015) aimed at increasing the proportion of renewable energy use to $30 \%$ of total final energy consumption in 2036 [3]. One of the sustainable energy sources is the conversion of waste to energy [4]. The government views solid waste as a means of reducing the electricity production costs of renewable energy as well as having social value and environmental benefits. According to the plan, the target of municipal solid waste ranks first to produce 500 megawatts of electricity [3]. Government policies have promoted the use of renewable energy among the large number of small power producers (SPPs) and very small power producers (VSPPs). The target in PDP 2015 was to increase the amount of renewable energy generation from waste to 500 megawatts [2], which was quickly achieved, and add a further 400 megawatts of renewable energy generation according to the Thailand Power Development Plan 2018 2037 (PDP 2018) [5]. Moreover, the government has introduced measures to support the purchase of electricity from Very Small Municipal Solid Waste Power Plants (VSMSWPPs) such as the Feed-in Tariff form [6]. Due to the government policies to reduce waste and ensure energy security, there have been an increasing number of the VSMSWPPs. The increasing number of VSPPs which use solid waste has led to questions as to whether or not they are successful and sustainable in Thailand, although case studies in other countries such as Japan, Sweden, Spain and Finland have shown positive outcomes. In Japan and the European Union (EU), solid waste power plants can reduce landfill waste, recover useful energy, and reduce GHG emission [7]. Sweden has an efficient system for managing municipal solid waste with most waste being recovered or reused, with only $4 \%$ going to landfill [8]. For Sweden, using waste to generate electricity is not solely about creating renewable energy. Rather, it is to preserve the world's natural resources that are finite, resulting in the construction of many waste-to-energy power plants [9]. In Scandinavia and Finland, energy production from solid waste energy is achieved by the application of technology that is of interest to the rest of the world who study and visit it [9].

Thus, the main objective of this study is to develop a conceptual framework and enumerate key success factors to evaluate the performance of the VSMSWPPs in Thailand which mainly use four types of technology; incinerator, gasification, anaerobic digestion, and landfill gas to energy. A recent study of these technologies in Southeast Asia found that the major waste-to-energy technologies are incinerator, 
landfill gas to energy, and anaerobic digestion. Each technology uses different type of waste to produce electricity, so each technology's waste management is different [10]. Furthermore, the present study intends to recommend a policy that encourages the good governance and sustainable management of VSMSWPPs. Moreover, it can be used as a guideline for executives and owners in the management of existing power plants as well as serve as a tool for new investors to determine the most suitable technology in order to coexist with surrounding communities.

\section{STUDY OBJECTIVES}

(1) To develop a governance and sustainability framework for Very Small Municipal Solid Waste Power Plant.

(2) To determine governance and sustainability key success factors for Very Small Municipal Solid Waste Power Plant.

\section{RESEARCH METHODOLOGY}

This study began with research of the documentation of the relevant sources drawn from records, data, statistics, textbooks, academic articles, and policies, as well as being built upon, the researcher's own first-hand experience of the waste and energy situation and attendance of a seminar which included a focus group on VSMSWPPs. This research served as the basis to determine the relevant indicators. The topics of the research of the documentation included: good governance, sustainable development concept, solid waste management, solid waste power plant, laws and policies related to solid waste management and power plants, very small power plants in Thailand, problems and obstacles in the management of waste power plant, evaluating the success of power plants, and key success factors.

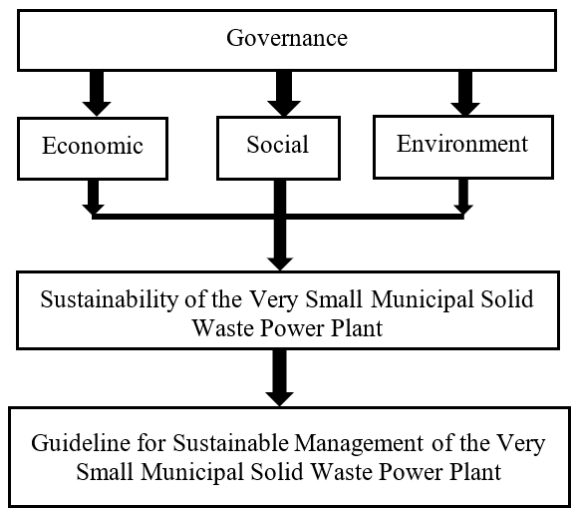

Figure 1. Conceptual framework

In addition, interviews were conducted with professionals, policy makers, practitioners and power plant owners to identify key success factors for evaluating governance and sustainability. Subsequently, the key success factors were sent to 12 key informants, that is, the solid waste power plant experts, academics, professionals, policy makers and entrepreneurs to comment on their appropriateness and overall coverage of all aspects in all dimensions for use in evaluating VSMSWPPs. The key informants commented upon the key success factors after which the key success factors were collected, grouped, analyzed, and summarized for revision according to their suggestions. The key success factors were purposively used to evaluate the performance of VSMSWPPs. The conceptual framework is shown in Figure 1. It consisted of four dimensions: governance, economic, social and environment according to the sustainability analysis concept [11].

\section{RESULTS}

\subsection{Framework and key success factor}

The initial key success factors were based upon from records, data, statistics, textbooks, academic articles, policies, as well as being built upon the researcher's own first-hand experience of the waste and energy situation and attendance of a seminar which included a focus group on VSMSWPPs. They are summarized in four dimensions: Governance, economic, social and environment, as shown in Figure 2.

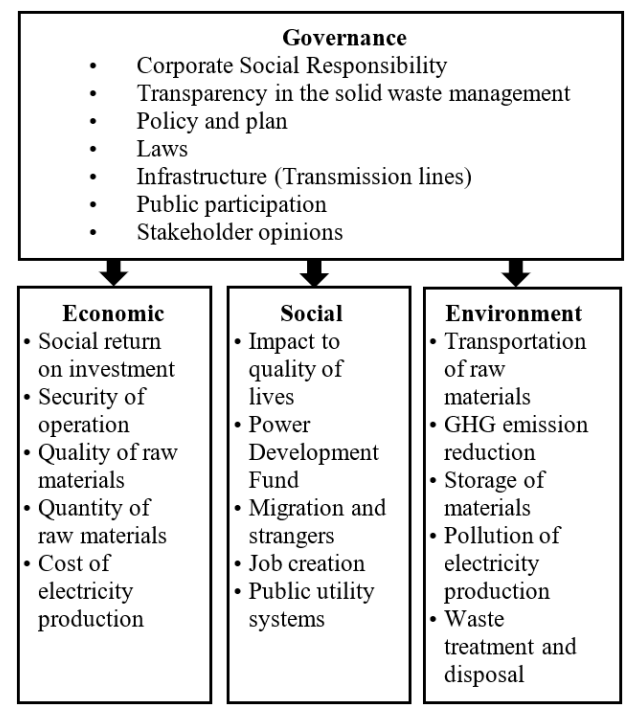

Figure 2. First draft of research framework

From the suggestions of the solid waste power plant experts, academics, professionals, policy makers and entrepreneurs, the conceptual framework was revised as shown in Figure 3.

The assessment of the conceptual framework by the solid waste power plant experts, academics, professionals, policy makers and entrepreneurs included the suggestions as follows:

\subsubsection{Governance dimension should include}

(1) Value of money: The cost effectiveness of the use of natural resources and environmental management.

(2) Power Development Fund: The collaboration between the government, the VSMSWPPs, and communities around the VSMSWPPs. The fund is a major component of the social responsibility of the VSMSWPPs.

\subsubsection{Economic dimension should include:}

(1) Infrastructure: the basic physical and organizational structures required for the operation of the VSMSWPPs. For instance, the electricity transmission lines in the area are sufficient and efficient to support the VSMSWPPs.

(2) Technology: Invest in the machinery and equipment used to efficiently generate electricity and minimize pollution.

(3) Economic return on investment: The final result of the operation of the VSMSWPPs in the economy compared to the investment. 
(4) Income of electricity production: In electricity production, entrepreneurs should consider both income and cost, including all revenue and expenses incurred in the performance of the VSMSWPPs.

(5) Financial support measures (Board of Investment offer): Government monetary policy to boost the VSMSWPPs construction, for example, financing, knowledge and innovation, and motivation to invest.

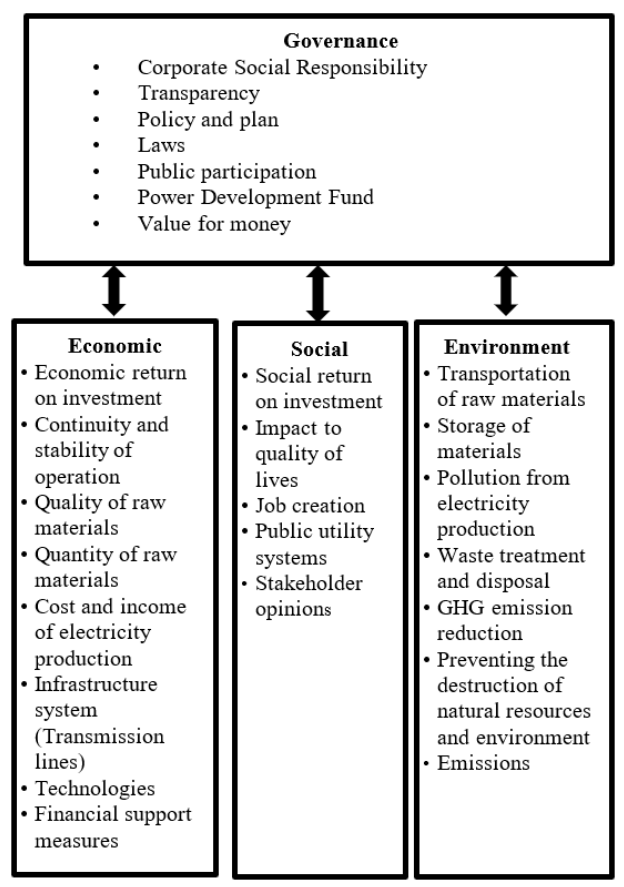

Figure 3. Revised research framework

\subsubsection{Social dimension should include}

(1) Social return on investment (SROI) as it considers three aspects leading to sustainable development. However, the following should not be included:

(2) Migration and stranger because they have little relationship with or knowledge of the development compared to workers who are typically local people. Within the power plant, the majority of workers labour with machinery, thus there are few management levels which required from outside the community.

\subsubsection{Environment dimension should include:}

(1) Preventing the destruction of natural resources and environment. The prevention of open burning should be taken into account as this waste disposal method emits a large amount of pollution.

(2) GHG emission reduction should be prioritized as well as minimization of other forms of polluting emission such as odour, dust (PM10, PM2.5), gas, fly ash and bottom ash.

The final framework is composed of four dimensions according to sustainability analysis concept. The four dimensions are governance, economic, social, and environment. These key factors indicate the means by which VSMSWPPs can succeed.

\subsection{Final key success factors for the Very Small Municipal Solid Waste Power Plant and their definitions}

The final key success factors were derived and defined in
Table 1. An example of key success factor in the governance dimension in Table 1 is corporate social responsibility which can be defined as the good ethical and responsible business practices, both socially and environmentally, that lead to sustainable development. This key success factor corresponds to a previous study which mentioned that success will promote others to begin investing in renewable energy, leading to the promotion of the social welfare of society [12]. A key success factor in the economic dimension is economic return on investment which was defined as the final result of the operation of the VSMSWPPs in the economy compared to the investment. In this regard, solid waste power plant has good profitability and economic benefits [13]. Key success factors in social dimension are quality of life, job creation and public utility systems which were affected by the management of the VSMSWPPs. Projects regarding the development of quality of life, job creation and construction and development of public utilities can be funded by a Power Development Fund [14]. A key success factor in the environment dimension is preventing the destruction of natural resources and environment, which was defined as the measures to protect natural resources and the environment in the vicinity of the VSMSWPPs. This can be achieved through the application of modern incineration technology with high removal efficiency in terms of volatile organic compounds (VOCs) of up to $99.99 \%$ but which may emit serious VOCs if temperature is unstable or combustion incomplete [15].

\subsection{Implementation}

Entrepreneurs or owners, enterprises, and cooperatives who manage VSMSWPPs can use this guideline for addressing issues or overcoming obstacles that occur in their operations. Moreover, new entrepreneurs in this field can apply the guideline to help in the decision-making process involved in selecting the appropriate technology for investment. The technology used is selected based on availability and suitability by using key success factor assessment. Technology selection should be based on the type, quality and quantity of waste/raw materials, capital, location, and appropriate pollution control systems to reduce resistance and public objection.

\section{CONCLUSION AND RECOMMENDATION}

The conceptual framework based on the sustainability analysis theory can be used as a tool to evaluate the governance and sustainability of the VSMSWPPs in Thailand. The conceptual framework provides a set of key success factors consisting of four dimensions. The governance dimension has seven key success factors; the economic dimension has eight key success factors; the social dimension has five key success factors; and the environment dimension has seven key success factors. These key success factors can be used to evaluate the efficiency of VSMSWPPs in several aspects. Decision-maker in management, entrepreneurs, or new entrepreneurs can use them to assess investment decisions when selecting technology and location which hinge on a range of factor. They can be used to evaluate VSMSWPPs and their potential, whether undertaken by the public sector or private sector which regard to growth with sustainability, green and circular economy. 
Table 1. Key success factors and definition for the very small municipal solid waste power plant

\begin{tabular}{|c|c|}
\hline Dimension & Key success factors \\
\hline \multirow[t]{7}{*}{ Governance } & Corporate social responsibility \\
\hline & $\begin{array}{c}\text { Transparency in the solid waste } \\
\text { management }\end{array}$ \\
\hline & Policy and plan \\
\hline & Laws \\
\hline & Public participation \\
\hline & Power Development Fund \\
\hline & Value for money \\
\hline \multirow[t]{6}{*}{ Economic } & Economic return on investment \\
\hline & $\begin{array}{c}\text { Continuity and stability of } \\
\text { operation }\end{array}$ \\
\hline & Quality of raw materials \\
\hline & Quantity of raw materials \\
\hline & $\begin{array}{l}\text { Cost and income of electricity } \\
\text { production }\end{array}$ \\
\hline & $\begin{array}{l}\text { Infrastructure system } \\
\text { (transmission line) }\end{array}$ \\
\hline
\end{tabular}

Technologies

Financial support measures

Good ethical and responsible business practices, both socially and environmentally, that lead to sustainable development.

References

The public, local administrative organization and stakeholders have sufficient information to understand and evaluate the performance of solid waste management used in the processes of the VSMSWPPs.

Formulation and implementation of policies and plans which the government announces for solid waste management and VSMSWPP management.

Formulation and implementation of laws for solid waste management and the VSMSWPPs in the local area.

People involvement in terms of their perceptions, comments, decisionmaking processes, and solving problems arising from the operation of the VSMSWPPs, including public participation in solid waste management and solid waste separation in the community.

Fund established by regulation of the six objectives issued by the

Energy Regulatory Commission for addressing problems in the communities around power plants resulting from the VSMSWPPs.

Cost effectiveness of the use of natural resources and environmental management.

Final outcome of the operation of the VSMSWPPs in the economy compared to the investment.

$[6,16,19$,

$[6,16,23-25]$

Continued functioning and stability of the VSMSWPPs based on the continued availability and suitability of raw materials, machinery, budget, persons and location.

Use of raw materials/waste in production processes which are suitable in terms of composition and characteristics and do not corrode or damage machinery.

Sufficient and cost effective raw materials/waste to produce electricity continually.

All revenue and expenses incurred in the performance of the VSMSWPPs.

Basic physical and organizational structures needed for the operation of VSMSWPPs. For instance, the electricity transmission lines in the area are sufficient and efficient enough to support the VSMSWPPs.

Machinery and equipment based on technology which the VSMSWPPs use to produce electricity in Thailand./ CONSIDER: Invest in the machinery and equipment used to efficiently generate electricity and minimize pollution.

Government monetary assistance to catalyze the VSMSWPPs, e.g., financing, knowledge, and innovation.

$[6,22,25$,

$[15,21,22$,

$33,35-37]$

The final result of the operation of the VSMSWPPs in society both in monetary terms such as revenue from the sale of electricity and waste

disposal fee and non-monetary terms such as waste disposal, environmental protection, energy security, and fertilizer compared with the cost of investment.

Management of the VSMSWPPs which affects the community and results in changing lifestyle, e.g., education support, health care, building utilities, economic support, community development and environmental degradation.

Job creation

Rise of employment in the community after the operation of the VSMSWPPs

An organization supplying the community with electricity, water or

Public utility systems

Stakeholder opinions

Environment

Transportation of raw materials

Storages of materials

Pollution from electricity production

Waste treatment and disposal sewerage. The development or alteration of these systems caused by the operation of the VSMSWPPs

Opinions of the policy makers, local government officers, power plant owner, executives, and community leaders and local people in around the VSMSWPPs.

Prevention of drop-down and leakage while transporting raw materials/waste to the VSMSWPPs, transportation distances, transportation monitoring, and problems and barriers in the transportation.

Suitability of the protection system for leakages, dust dispersion, and odour of raw materials/waste storage facilities of the VSMSWPPs. VSMSWPPs produce wastewater, solid waste, and air pollution and must have suitable, effective, and efficient pollution control systems. Management of waste arising from the operation of the VSMSWPPs, such as wastewater and solid waste. The waste is managed according to the technical requirements, laws, and regulations.

$[30,32,33$, 


\begin{tabular}{|c|c|c|c|}
\hline Dimension & Key success factors & Definition & References \\
\hline \multirow[t]{3}{*}{$\begin{array}{l}\text { Environment } \\
\text { (Continue) }\end{array}$} & $\begin{array}{l}\text { Greenhouse gas }(\mathrm{GHG}) \text { emission } \\
\text { reduction }\end{array}$ & $\begin{array}{l}\text { Difference in GHG emissions of the VSSWPP in comparison to other } \\
\text { types of non-renewable power plant. }\end{array}$ & $\begin{array}{c}{[29,33]} \\
{[37,40,45]}\end{array}$ \\
\hline & $\begin{array}{l}\text { Preventing the destruction of } \\
\text { natural resources and } \\
\text { environment }\end{array}$ & $\begin{array}{c}\text { The measures of VSMSWPPs to protect natural resources and } \\
\text { environment }\end{array}$ & {$[31,33]$} \\
\hline & Emissions & All releases from operation of the VSMSWPPs. & $\begin{array}{l}{[15,33,40,} \\
43,46]\end{array}$ \\
\hline
\end{tabular}

\section{REFERENCES}

[1] The Secretariat of the Cabinet (Thailand). (2014). Policy Statement of the council of ministers. Cabinet and Royal Gazette Publishing Office, Bangkok, Thailand. https:/www.thaigov.go.th/aboutus/current/policystatement.

[2] Energy Policy and Planning Office (Thailand). (2015). Thailand Power development plan 2015-2036 (PDP2015). Energy Policy and Planning Office, Bangkok, Thailand. https://www.egat.co.th/en/images/aboutegat/PDP2015_Eng.pdf.

[3] Department of Renewable Energy Development and Energy Efficiency (Thailand). (2015). Alternative energy development plan: AEDP 2015. Ministry of Energy, Bangkok, Thailand https://www.dede.go.th/download/files/AEDP2015_Fin al_version.pdf.

[4] Tsai, W.T. (2016). Analysis of municipal solid waste incineration plants for promotion power generation efficiency in Taiwan. Journal Mater Cycle Waste Manage, 18: 393-388. https://doi.org/10.1007/s10163014-0345-8

[5] Energy Policy and Planning Office (Thailand). (2019). Thailand Power Development Plan 2018-2037 (PDP2018). Energy Policy and Planning Office, Bangkok, Thailand. http://www.eppo.go.th/images/POLICY/PDF/PDP2018. pdf.

[6] Energy Regulatory Commission (Thailand). (2016). Notification of the energy regulatory commission: electricity supply for power generation projects from community waste in the form of feed-in tariff (FiT) B.E.2559. Bangkok, Thailand. http://www.erc.or.th/ERCWeb2/Upload/Document/\%E $0 \% \mathrm{~B} 8 \% 9 \mathrm{~B} \% \mathrm{E} 0 \% \mathrm{~B} 8 \% \mathrm{~A} 3 \% \mathrm{E} 0 \% \mathrm{~B} 8 \% \mathrm{~B} 0 \% \mathrm{E} 0 \% \mathrm{~B} 8 \% 81$ $\%$ E0\%B8\%B2\%Е0\%B8\%A $8 \% 20 \%$ E0\%B8\%81\%Е0\% B8\%81\%E0\%B8\%9E\%20\%2016\%20-2559.pdf.

[7] Ham, G., Lee, D. (2017). Consideration of high-efficient Waste-to-Energy with district energy for sustainable solid waste management in Korea. Energy Procedia, 116: 518-526. https://doi.org/10.1016/j.egypro.2017.05.099

[8] Sverigr, A. (2009) Towards a greener future with swedish waste-to energy; the world's best example, Swedish Waste Management, Malmö, Sweden.

[9] Tinsuntisook, P. (2014). Green RDF Power: Thailand VS Sweden. Modern Manufacturing Magazine, 12(133): 6871.

[10] Tun, M.M., Palacky, P., Juchelkova, D., Sítar, V. (2020). Renewable Waste-to-Energy in Southeast Asia: Status, Challenges. Opportunities, and Selection of Waste-toEnergy Technologies. Applied Sciences, 10(20): 7312. https://doi.org/10.3390/app10207312
[11] UN Documents. (1987). Our Common Future: Report of the world Commission on Environment and Development. New York, United Nations.

[12] Mezher, T., Tabbara, S., Al-Hosany, N. (2010). An overview of CSR in the renewable energy sector: Examples from the Masdar Initiative in Abu Dhabi. Management of Environmental Quality, An International Journal, 21(6): 744-760. https://doi.org/10.1108/14777831011077619

[13] Zhao, X., Jiang, G., Li, A., Li, Y. (2016). Technology, cost, a performance of waste-to-energy incineration industry in China. Renewable and Sustainable Energy Reviews, 55: 115-130. https://doi.org/10.1016/j.rser.2015.10.137

[14] Energy Regulatory Commission (Thailand). (2014). Public Guide Second book: Community Development Guide and Recommendations. Energy Regulatory Commission, Bangkok, Thailand.

[15] Liu, S., Wang, B., He, J., Tang, X., Luo, W., Wang, C. (2012). Source fingerprints of volatile organic compounds emitted from a municipal solid waste incineration power plant in Guangzhou, China. Procedia Environmental Science, 12: 106-115. https://doi.org/10.1016/j.proenv.2012.01.254

[16] Chailertpong, T., Phimolsathien, T. (2018). Solving global problem: Waste to power while creating stakeholder share value. Business and Economic Horizons, 14(1): 54-74. https://dx.doi.org/10.15208/beh.2018.5

[17] Office of the Civil Service Commission (Thailand). (2011). A guideline for creating transparency standard for government agencies. Office of the Civil Service Commission, Bangkok, Thailand. http://www.bpp41.go.th/manual_gp.pdf.

[18] Bertocchi, M. (2017). Transparency in local state-owned enterprises in Italy. Symphonya. Emerging Issues in Management (symphonya.unimib.it), 2: 31-46. https://doi.org/10.4468/2017.2.04bertocchi

[19] Fobissie, E.N. (2019). The role of environmental values and political ideology on public support in Ottawa, Canada. Energy Policy, 134: 1-9. https://doi.org/10.1016/j.enpol.2019.110918

[20] Mezher, T., Dawelbait, G., Abbas, Z. (2012). Renewable energy policy options for Abu Dhabi: Drivers and barriers. Energy Policy, 42: 315-328. https://doi.org/10.1016/j.enpol.2011.11.089

[21] Johnstone, N., Managi, S., Rodríguez, M.C., Haščič, I., Fujii, H., Souchier, M. (2017). Environmental Policy design, innovation and efficiency gains in electricity generation. Energy Economics, 63: 106-115. https://doi.org/10.1016/j.eneco.2017.01.014

[22] Bundhoo, Z.M.A. (2018). Solid waste management in least developed countries: Current status and challenges faced. Journal of Material Cycle and Waste Management, 
20: 1867-1877. https://doi.org/10.1007/s10163-0180728-3

[23] Chompunth, C. (2011). An evaluation of public participation practice in environmental development projects in Thailand: A case study of the Hin Krut Power Plant Project. Unpublished PhD thesis, University of East Anglia, Norwich, UK.

[24] Gupta, N., Gupta, R. (2015). Solid waste management and sustainable cities in India: The case of Chandigrarh. Environment \& Urbanization, 27(2): 573-588. https://doi.org/10.1177/0956247815581747

[25] Yukalang, N., Dawn, CB., Ross, KE. (2017). Solid waste management in Thailand: an overview and case study (Tha Khon Yang sub-district). Reviews on Environmental Health, 32(3): 223-234. https://doi.org/10.1515/revek.2016-0061

[26] Energy Regulatory Commission (Thailand). (2020). The notification of the energy regulatory commission on criteria and method for allocation of power development fund for local development or rehabilitation affected by the power plant operation B.E. 2020. Energy Regulatory Commission, Thailand.

[27] Putarungsi, P. (2020). Development of conceptual framework and indicators for assessment of power development fund in Thailand. Kasetsart Journal of Social Sciences, 41: 8-14. https://doi.org/10.1016/j.kjss2018.06.003

[28] Department of Alternative Energy Development and Efficiency (Thailand). (2003). Study and demonstration of electricity/heat production from community waste; complete report:1, Bangkok, Thailand. https://webkc.dede.go.th/testmax/sites/default/files/\%E0 $\%$ B $8 \%$ A3\%E0\%B8\%B2\%E0\%B8\%A2\%E0\%B8\%87\% Е0\%B8\%B2\%Е0\%B8\%99\%20\%Е0\%B9\%80\%Е0\%B8 $\%$ A5\%Е0\%B9\%88\%Е0\%B8\%A1\%Е0\%B8\%97\%Е0\% B8\%B5\%E0\%B9\%88\%201.pdf.

[29] Ayodele, T.R., Alao, M.A., Ogunjuyigbe, A.S.O. (2018) Recyclable resources from municipal solid waste: Assessment of its energy, economic and environmental benefits in Nigeria. Resources, Conservation and Recycling, 134: $165-173$ https://doi.org/10.1016/j.resconrec.2018.03.017

[30] Rand, T., Haukohl, J., Marxen, U. (2000). Municipal solid waste incineration: Requirement for successful project. World Bank Publication, Washington, D.C., USA.

[31] Phoochinda, W. (2012). Environmental impact and measures of electricity generation for very small power plant using renewable energy. The Journal of KMUTNB., 22(1): 118-130.

[32] Suppasedsek, W. (2019). Municipal solid waste problem and its solution with waste to energy power plant project. The National Defence College of Thailand Journal, 61(3): 108-119.

[33] Panepinto, D., Viggiano, F., Genon, G. (2014). Evaluation of environmental compatibility for a biomass plant. Waste Biomass Valorization, 5: 759-772. https://doi.org/10-1007/s12649-014-9300-0

[34] Lohri, C.R., Camenzind, E.J., Zurbrügg, C. (2014). Financial sustainability in municipal solid waste management - cost and revenues in Bahir Dar, Ethiopia. Waste Management, 34: 542-552. https://doi.org/10.1016/j.wasman.2013.10.014

[35] Tomić, T., Schneider, D.R. (2017). Municipal solid waste system analysis through energy consumption and return approach. Journal of Environmental Management, 203: 972-987. https://doi.org/10.1016/j.jenvman.2017.06.070

[36] Tang, Y., You, F. (2017). Multicriteria environmental and economic analysis of municipal solid waste incineration power plant with carbon capture and separation from the life-cycle perspective. ACS Sustainable Chemistry and Engineering, 6(1): 937-956. https://doi.org/10.1021/acssuschemeng.7b03283

[37] Behzadi, A., Houshfar, E., Gholamian, E., Ashjaee, M., Habibollahzade, A. (2018). Multi-criteria optimization and comparative performance analysis of a power plant fed by municipal solid waste using a gasifier or digester. Energy Conversion and Management, 171: 863-878. https://doi.org/10.1016/j.enconman.2018.06.014

[38] Ozturk, M., Yuksel, Y.E. (2016). Energy structure of Turkey for sustainable Development. Renewable and Sustainable Energy Reviews, 53: 1259-1272. https://doi.org/10.1016/j.rser.2015.09.087

[39] Hadjilambrinos, C. (2019). Renewable energy development as a job creation mechanism: Lessons from New Mexica. Journal of Research and Innovation for Sustainable $\quad$ Society, $1(2)$ : 36-43. https://doi.org/10.33727/JRISS.2019 2.5:36-43

[40] Easterly, J.L. (1996). Overview of biomass and waste fuel resources for power production. Biomass and Bioenergy, 10(2-3): 79-92. https://doi.org/10/1016/0961-9534(95)00063-1

[41] Muñoz, E., Vargas, S., Navia, R. (2015). Environmental and economic analysis of residue woody biomass transport for energetic use in Chili. International Journal Life Cycle Assess, 20: 1033-1043. https://doi.org/10.1007/s11367-015-0891-x

[42] Photikun, A. (2018). Community waste management of Sansuk municipality, Sriracha District, Chonburi province. Journal of Pacific Institute of Management Science (Humanities and Social Science), 4(1): 107-122.

[43] Phoochinda, W. (2014). Appropriate environmental management of electricity generation from renewable energy. International Journal of Sustainable Development and Planning, 9(6): 812-829. https://doi.org/10.2495/SDP-V9-N6-812-829

[44] Li, J., Dong, H., Sun, J., Nie, J., Zhaang, S., Tang, J., Chem, Z. (2016). Composition profiles and health risk of $\mathrm{PCDD} / \mathrm{F}$ in outdoor air and fly ash from municipal solid waste incineration and adjacent villages in East China. Science of the Total Environment, 571: 876-882. https://dx.doi.org/10.1016/j.scitotenv.2016.07.06

[45] Aja, O.C., Al-Kayiem, H.H. (2014). Review of municipal solid waste management options in Malaysia, with an emphasis on sustainable waste-to-energy options. Journal of Material Cycles Waste Management, 16: 693710. https://doi.org/10.1007/s10163-013-0220-z

[46] Edo, M., Skoglund, N., Gao, Q., Persson, P.E., Jansson, S. (2017). Fate of metals and emissions of organic pollutants from torrefaction of waste wood, MSW, and RDF. Waste Management, 68: 646-652. https://doi.org/10.1016/j.wasman.2017.06.017 